\title{
IMAGEAMENTO DA POROSIDADE ATRAVÉS DE PERFIS GEOFÍSICOS DE POÇO
}

\author{
Anna Ilcéa Fischetti Miranda \\ Orientador: Dr. André José Neves Andrade (UFPA) \\ 57 p. - Tese (Doutorado) - Defesa 14.01.2004
}

RESUMO. 0 imageamento da porosidade é uma representação gráfica da distribuição lateral da porosidade da rocha, estimada a partir de dados de perfis geofísicos de poço. Apresenta-se aqui uma metodologia para produzir esta imagem geológica, totalmente independente da intervenção do intérprete, através de um algoritmo, dito, interpretativo baseado em dois tipos de redes neurais artificiais. A primeira parte do algoritmo baseia-se em uma rede neural com camada competitiva e é construído para realizar uma interpretação automática do clássico gráfico $\rho_{b}-\phi_{N}$, produzindo um zoneamento do perfil e a estimativa da porosidade. A segunda parte baseia-se em uma rede neural com função de base radial, projetado para realizar uma integração espacial dos dados, a qual pode ser dividida em duas etapas. A primeira etapa refere-se à correlação de perfis de poço e a segunda à produção de uma estimativa da distribuição lateral da porosidade. Esta metodologia ajudará o intérprete na definição do modelo geológico do reservatório e, talvez o mais importante, o ajudará a desenvolver de um modo mais eficiente as estratégias para o desenvolvimento dos campos de óleo e gás. Os resultados ou as imagens da porosidade são bastante similares às seções geológicas convencionais, especialmente em um ambiente deposicional simples dominado por clásticos, onde um mapa de cores, escalonado em unidades de porosidade aparente para as argilas e efetiva para os arenitos, mostra a variação da porosidade e a disposição geométrica das camadas geológicas ao longo da seção. Esta metodologia é aplicada em dados reais da Formação Lagunillas, na Bacia do Lago Maracaibo, Venezuela.

ABSTRACT. Porosity images are graphical representations of the lateral distribution of rock porosity estimated from well log data. We present a methodology to produce this geological image entirely independent of interpreter intervention, with an interpretative algorithm approach, which is based on two types of artificial neural networks. The first is based on neural competitive layer and is constructed to perform an automatic interpretation of the classical $\rho_{b}-\phi_{N}$ cross-plot, which produces the log zonation and porosity estimation. The second is a feed-forward neural network with radial basis function designed to perform a spatial data integration, which can be divided in two steps. The first refers to well log correlation and the second produces the estimation of lateral porosity distribution. This methodology should aid the interpreter in defining the reservoir geological model, and, perhaps more importantly, it should help him to efficiently develop strategies for oil or gas field development. The results or porosity images are very similar to conventional geological cross-sections, especially in a depositional setting dominated by clastics, where a color map scaled in porosity units illustrates the porosity distribution and the geometric disposition of geological layers along the section. The methodology is applied over actual well log data from the Lagunillas Formation, in the Lake Maracaibo basin, located in western Venezuela. 